\title{
The Effects of Calcium Fertilizer Sprays during Fruit Development Stage on Pineapple Fruit Quality under Humid Tropical Climate
}

\author{
Supriyono Loekito $\mathbb{D}^{1},{ }^{1}$ Afandi $\mathbb{D}^{2},{ }^{2}$ Auliana Afandi $\mathbb{D}^{,},{ }^{3}$ Naomasa Nishimura, ${ }^{4}$ \\ Hiroyuki Koyama $\mathbb{D D}^{4}$ and Masateru Senge ${ }^{5}{ }^{5}$ \\ ${ }^{1}$ Research and Development Department, PT Great Giant Pineapple, Jl. Raya Terbanggi Km 77, Central Lampung, \\ Lampung 34163, Indonesia \\ ${ }^{2}$ Department of Soil Science, Faculty of Agriculture, Lampung University, J. Sumantri Brojonegoro 1, Bandar Lampung, \\ Lampung 35145, Indonesia \\ ${ }^{3}$ Department of Plant Protection, Faculty of Agriculture, Lampung University, J. Sumantri Brojonegoro 1, Bandar Lampung, \\ Lampung 35145, Indonesia \\ ${ }^{4}$ Faculty of Applied Biological Science, Gifu University, 1-1 Yanagido, Gifu, Japan \\ ${ }^{5}$ Gifu University Laboratory, 1-1 Yanagido, Gifu, Japan
}

Correspondence should be addressed to Supriyono Loekito; supriyono.loekito@ggpc.co.id

Received 24 July 2021; Accepted 22 December 2021; Published 17 January 2022

Academic Editor: Magdi Abdelhamid

Copyright (c) 2022 Supriyono Loekito et al. This is an open access article distributed under the Creative Commons Attribution License, which permits unrestricted use, distribution, and reproduction in any medium, provided the original work is properly cited.

\begin{abstract}
Low calcium content in pineapple could decrease its quality, such as fruit translucency (electrolyte leakage), bruises (fruit firmness), and the other fruit quality standards. The purpose of the current study was to assess the effect of different sprays of calcium $(\mathrm{Ca})$ fertilizer sources during the fruit development stage on the overall fruit quality. Four sources of calcium, chelated calcium, calcium nitrate $\left(\mathrm{Ca}\left(\mathrm{NO}_{3}\right)_{2}\right)$, calcium chloride $\left(\mathrm{CaCl}_{2}\right)$, each in $75 \mathrm{~kg} \mathrm{ha}^{-1}$, and calcium boron (calcibor) of $10 \mathrm{~L} \mathrm{ha}{ }^{-1}$ mixed with $2000 \mathrm{~L}$ water, were directly sprayed onto individual fruit and crown, 75, 85, 95, and 105 days after forced flowering induction (forcing). The Smooth Cayenne "MD-2" pineapple cultivar was utilized for the experiment in a randomized complete block design with four replications and conducted at two different times. Fruit quality analyses were carried out on the harvested fruits 140 days after forcing. The application of calcium sprays did not have significant effects on fruit $p H$, total soluble solids, total acidity, fruit firmness, and the content of sucrose and vitamin C. There was a different response of calcium spray in the first and second trials on the content of glucose, fructose, $\beta$-carotene, $\mathrm{Ca}$, and $\mathrm{Mg}$, probably due to climate condition. All treatments with calcium sprays reduced the fructose and glucose contents in the first trial and $\beta$-carotene content in the second trial. Calcium chloride and calcibor increased $\mathrm{Ca}$ and decreased electrolyte leakage significantly than the other treatments. The scanning electron microscope analysis revealed that $\mathrm{CaCl}_{2}$ sprays generated greater turgor and more rigidity in the pineapple cell wall. The result showed that the application of $\mathrm{CaCl}_{2}$ and calcibor sprays could decrease electrolyte leakage incidence in pineapple with any potential to reduce glucose, fructose, and $\beta$-carotene without influencing other fruit qualities significantly.
\end{abstract}

\section{Introduction}

Pineapple (Ananas comosus L. Merr) is one of the most economically important fruits traded in the global market. The fruit quality, in terms of both inside and outside physical appearance, is very important especially when the pineapple is cultivated for the fresh fruit business, rather than for canned pineapple. Mechanical injury, translucency, chilling injury, and postharvest disease are the main causes of postharvest losses [1]. In some pineapple plantations at PT Great Giant Pineapple (GGP) in Indonesia, fruit translucency, decay, bruises, peduncle mold, wet peduncles, and so on are the defects that have caused a decrease in the overall quality of the fruit and caused sales claims. The total claims 
for the total sales of GGP's exported fresh pineapple in the year 2020 reached 5.2\% for Middle East destinations and 22.9\% for Asian destinations.

Calcium ions are known to be an essential plant nutrient involved in a number of physiological processes [2]. Calcium sprays, mostly as $\mathrm{Ca}$ chloride or $\mathrm{Ca}$ nitrate, are recommended and applied in many parts of the world to improve fruit quality [3]. It is known that calcium plays an important role in the maintenance of membrane integrity [4] and is required for the synthesis of new cell walls and for the normal function of the plant membranes [5]. Application of calcium sprays could reduce the incidence of internal browning or black heart disorder in Mauritius pineapple [6] and translucency incidence [7]. Calcium chloride $\left(\mathrm{CaCl}_{2}\right)$ enhanced vegetative growth parameters, yield, and fruit quality traits and reduced fruit cracking and sunburn damage of fruit of Manfalouty pomegranate trees [8]. Preharvest $\mathrm{CaCl}_{2}$ sprays raised Ca concentrations in leaves and fruit and increased flesh firmness of "Elstar" apple trees [9]. Application of early preharvest foliar Ca sprays increased fruit quality of highbush blueberry "Liberty" (V. corymbosum) fruits with firmer fruit, increased fruit $\mathrm{Ca}$ levels, total phenolic content, and the proportion of sound fruits, and reduced the percentage of dehydrated and decayed berries after storage [10]. Fruit Ca uptake continues throughout fruit development; therefore, Ca application during bloom and early fruit development may prevent or minimize Ca deficiency disorders in bell pepper (Capsicum annuum L.) [11]. Calcium carbonate and calcium citrate are the main calcium salt added to foods to enhance the nutritional value [12]. Bioavailability and solubility are the most important factors in choosing an appropriate source of calcium [13].

It has been reported that pineapple has a very low requirement for calcium; the level of $\mathrm{Ca}$ adequacy for soil has been reported as 100-150 $\mathrm{mg} \mathrm{kg}^{-1}$, and for pineapple "MD2 ," the level of nutrient leave adequacy has been reported as $4.4 \mathrm{~g} \mathrm{~kg}^{-1}$ [14]. During the fruit development stage, calcium was needed to increase fruit quality and prevent fruits defects, and foliar spray of calcium was needed to overcome this problem. There are several calcium sources available in the market, such as calcium nitrate, calcium boron, calcium chloride, chelate calcium $(9.5 \% \mathrm{Ca})$, and $9.5 \%$ chelated calcium (using EDTA agent) that can be sprayed onto the pineapple plant. However, the report of the effects of calcium from different sources on the fruit quality of pineapple was limited, especially on their use on "MD-2" pineapple during the fruit development stage and under a humid tropical climate.

So this study was conducted to evaluate the effect of several sources of calcium when they were sprayed during the fruit development stage in "Smooth Cayenne" pineapple "MD-2" on the quality of pineapple fruit.

\section{Materials and Methods}

2.1. Site Description. The research was conducted in a pineapple field of the PT GGP plantation in Lampung, Indonesia. The experimental station has the following geographic coordinates: latitude $04^{\circ} 49^{\prime} 13^{\prime \prime}$ South and longitude $105^{\circ} 13^{\prime} 13^{\prime \prime}$ East, with an average altitude of around $46 \mathrm{~m}$. The soil was sandy clay loam of red yellow podzolic soil or Ultisol with rainfall of about $2,500 \mathrm{~mm}$ per year. The cultivar used for this experiment was "Smooth Cayenne" "MD-2." The research was conducted twice: the first was between June and August in 2020 and the second from August to October in 2020. The soil characteristics are described in Table 1. Using a manual weather station, the total rainfall during the experiment was $808.4 \mathrm{~mm}$ with relative humidity $(\mathrm{RH})$ around $90.7 \%$, and an average, maximum, and minimum monthly air temperature was $27.3,32.0$, and $23.9^{\circ} \mathrm{C}$, respectively (Table 2). Solar radiation ranged from 15.0 to $16.2 \mathrm{~W} \mathrm{~m}^{-2}$, which was detected from LSI Lastem data.

2.2. Experimental Design. The experiment consisted of five treatments of calcium sprays with different doses and the untreated control. The calcium treatments of calcium nitrate, calcium chloride, and chelated calcium, all in doses of $75 \mathrm{~kg} \mathrm{ha}^{-1}$ mixed in $2000 \mathrm{~L}$ water $(3.75 \% \mathrm{wt})$, and that of calcium boron, in a dose of $10 \mathrm{~L} \mathrm{ha}^{-1}$ mixed in $2000 \mathrm{~L}$ water $(0.5 \% \mathrm{vol})$, were sprayed directly onto each individual fruit, including the crown at night time when the stomata were opened. The doses were executed 75, 85, 95, and 105 days after forcing (DAF). The control was a sample without any application of calcium from the beginning of the research until the pineapple harvest. The experiment was arranged in a randomized completed block design with four replications using 20 plants per replication. Each plot was composed of five rows, $0.55 \mathrm{~m}$ in width and $5 \mathrm{~m}$ in length. An analysis of the available information on the uptake and mobility of the calcium after the flower induction in the pineapple fruit is described in $[14,15]$. A detailed summary of the treatments is given in Table 3 .

2.3. Analysis of Fruit Quality. The pineapple quality criteria examined were fruit $\mathrm{pH}$, TSS (total soluble solids), TA (total acidity), $\beta$-carotene, vitamin $\mathrm{C}$, fructose, glucose, sucrose, calcium content, magnesium content, EL (electrolyte leakage), firmness, and SEM (scanning electron microscope) examination of "Smooth Cayenne" pineapple "MD-2." The fruit flesh $\mathrm{pH}$, TSS, and TA were calculated based on the procedure described by Shamsudin et al. [16]. The fruit flesh $p H$ was measured using a conventional electronic $\mathrm{pH}$ meter (METTLER TOLEDO, USA) equipped with a penetration electrode model. The TSS was calculated using a hand-held refractometer (MASTER-53 $\alpha$, Atago, Japan). The TA was detected by titration to the $p H 8.1$ with $0.1 \mathrm{~mol} \mathrm{~L}^{-1} \mathrm{NaOH}$ using phenolphthalein as an indicator and revealed as a percentage of citric acid.

The firmness of the pineapple fruit flesh was measured according to Ding and Syazwani [17]. A type of Brookfield Ametek CT3 texture analyzer with a $7 \mathrm{~mm}$ flat probe was used for this method.

The calcium and magnesium contents of the pineapple fruit were analyzed using atomic absorption spectrometry (AAS 932 Plus, GBC scientific equipment, USA), as described by Benton-Jones [18]. 
TABLE 1: Characteristics of the soil in the experiment.

\begin{tabular}{|c|c|c|c|}
\hline \multicolumn{2}{|c|}{ Property } & \multirow{2}{*}{$\begin{array}{c}\text { 1st trial } \\
25.0\end{array}$} & \multirow{2}{*}{$\begin{array}{c}\text { 2nd trial } \\
32.8\end{array}$} \\
\hline & Clay (wt\%) & & \\
\hline Soil particle & Loam (wt\%) & 8.4 & 8.3 \\
\hline & Sand (wt\%) & 66.6 & 58.9 \\
\hline \multirow{8}{*}{ Chemical properties } & $p H\left(\mathrm{H}_{2} \mathrm{O}\right)$ & 4.0 & 4.4 \\
\hline & $\mathrm{C}(\mathrm{wt} \%)$ & 1.06 & 1.23 \\
\hline & $\mathrm{N}\left(\mathrm{mg} \mathrm{kg}^{-1}\right)$ & 550.0 & 640.0 \\
\hline & $\mathrm{P}\left(\mathrm{mg} \mathrm{kg}^{-1}\right)$ & 23.3 & 9.1 \\
\hline & $\mathrm{K}\left(\mathrm{mg} \mathrm{kg}^{-1}\right)$ & 89.7 & 58.5 \\
\hline & $\mathrm{Ca}\left(\mathrm{mg} \mathrm{kg}^{-1}\right)$ & 38.0 & 64.0 \\
\hline & $\operatorname{Mg}\left(\mathrm{mg} \mathrm{kg}^{-1}\right)$ & 6.0 & 4.8 \\
\hline & $\mathrm{Na}\left(\mathrm{mg} \mathrm{kg}^{-1}\right)$ & 9.2 & 6.9 \\
\hline
\end{tabular}

TABLE 2: Monthly rainfall and air temperature during the experiment in 2020.

\begin{tabular}{lccccc}
\hline Month & Rainfall $(\mathrm{mm})$ & Maximum & $\begin{array}{c}\text { Temperature }\left({ }^{\circ} \mathrm{C}\right) \\
\text { Minimum }\end{array}$ & Average & Relative humidity $(\%)$ \\
\hline June & 318.5 & 31.6 & 24.4 & 27.0 & 92.3 \\
July & 101.5 & 31.2 & 23.7 & 27.1 & 92.4 \\
August & 125.8 & 32.7 & 23.5 & 27.9 & 89.2 \\
September & 91.9 & 32.2 & 23.6 & 26.8 & 87.2 \\
October & 170.7 & 32.3 & 24.1 & 27.8 & 92.3 \\
Average & & 32.0 & 23.9 & 27.3 & 90.7 \\
Total & 808.4 & - & - & - & - \\
\hline
\end{tabular}

TABLE 3: Characteristics of the treatments used in the experiment.

\begin{tabular}{|c|c|}
\hline Treatment & Characteristic \\
\hline Control & Untreated \\
\hline $\mathrm{CaB}$ & Calcium boron sprayed in doses of $10 \mathrm{~L} \mathrm{ha}^{-1}$ in $2000 \mathrm{~L}$ water, applied $75,85,95$, and $105 \mathrm{DAF}$ \\
\hline $\mathrm{CaN}$ & $\mathrm{Ca}\left(\mathrm{NO}_{3}\right)_{2}$ applied in doses of $75 \mathrm{~kg} \mathrm{ha}^{-1}$ in $2000 \mathrm{~L}$ water, applied $75,85,95$, and $105 \mathrm{DAF}$ \\
\hline $\mathrm{CaCl}$ & $\mathrm{CaCl}_{2}$ applied in doses of $75 \mathrm{~kg} \mathrm{ha}^{-1}$ in $2000 \mathrm{~L}$ water, applied $75,85,95$, and $105 \mathrm{DAF}$ \\
\hline CaChe & CaChe applied in doses of $75 \mathrm{~kg} \mathrm{ha}^{-1}$ in $2000 \mathrm{~L}$ water, applied $75,85,95$, and $105 \mathrm{DAF}$ \\
\hline
\end{tabular}

* DAF: day after forcing.

The detection of the sugar and vitamin $\mathrm{C}$ (ascorbic acid) contents in the pineapple fruit was done using a High Performance Liquid Chromatography (Hitachi, USA) model L-2000 instrument with a Refractive Index detector model L-2490. The method is described by Siti Roha et al. [19].

The $\beta$-carotene content of the pineapple fruit was detected by the method described by Owolade et al. [20] using a Spectroquant ${ }^{\circledR}$ Pharo 300. Similar to the sugar content, the samples were collected from a composition of four fruits per replication from each treatment arranged.

The electrolyte leakage of fruit flesh was measured using the methodology described in Chen and Paull [15]. A composition of five fruits per treatment was created by applying a longitudinal plug with a cork borer and then slicing disks $2 \mathrm{~mm}$ in thickness. The amount of $6 \mathrm{~g}$ per disk was then washed three times to remove any lysed material from the cell. After that, the disks were shaken and incubated in $60 \mathrm{ml}$ of $0.3 \mathrm{M}$ mannitol solution for two hours. The conductivity of the previous solution was measured with a radiometer. Finally, the samples were boiled for around two hours to release all the electrolytes before the conductivity was determined. The electrolyte leakage is shown as the percentage of the total conductivity.

To display the SEM examination results for the samples of the first trial, the procedure for the observation followed that described by $\mathrm{Hu}$ et al. [21]. The observation was carried out with an SEM (ZEISS/EVO MA 10, German) equipped with energy dispersive spectroscopy (EDS) at $20 \mathrm{kV}$ for the detached slides of $\left(5 \times 5 \times 2 \mathrm{~mm}^{3}\right)$ of fruit flesh.

2.4. Statistical Analysis. Statistical examinations were performed using SPSS Version 22.0 software (SPSS Inc., Chicago, IL, USA). All the data were analyzed by ANOVA. The mean significant differences at $P<0.05$ were determined by Duncan's new multiple range test.

\section{Results}

3.1. Effect of Calcium Spray on pH, TSS, and TA of Pineapple Fruit. In both trials, the application of calcium did not have significant effects on $p H$, TSS, and TA in fruit flesh (Table 4), 
TABLE 4: Effect of calcium sprays on $p H$, TSS, and TA in fruit flesh.

\begin{tabular}{|c|c|c|c|c|c|c|}
\hline \multirow{2}{*}{ Treatment } & \multicolumn{2}{|c|}{$p H$} & \multicolumn{2}{|c|}{ Total soluble solid (wt\%) } & \multicolumn{2}{|c|}{ Total acidity (wt\%) } \\
\hline & $1 \mathrm{st}$ & 2nd & 1 st & 2nd & 1 st & 2nd \\
\hline Control & $3.84 \pm 0.05^{a}$ & $3.90 \pm 0.04^{a}$ & $14.30 \pm 0.24^{a}$ & $14.70 \pm 0.24^{a}$ & $0.34 \pm 0.02^{a}$ & $0.48 \pm 0.03^{a}$ \\
\hline $\mathrm{CaN}$ & $3.77 \pm 0.06^{a}$ & $3.85 \pm 0.11^{a}$ & $13.90 \pm 0.06^{a}$ & $14.15 \pm 0.17^{a}$ & $0.37 \pm 0.02^{a} \mathrm{~b}$ & $0.51 \pm 0.05^{a}$ \\
\hline $\mathrm{CaB}$ & $3.77 \pm 0.06^{a}$ & $3.93 \pm 0.04^{a}$ & $13.95 \pm 0.26^{a}$ & $14.55 \pm 0.19^{a}$ & $0.38 \pm 0.02^{a} \mathrm{~b}$ & $0.50 \pm 0.02^{a}$ \\
\hline $\mathrm{CaCl}$ & $3.86 \pm 0.07^{a}$ & $3.78 \pm 0.04^{a}$ & $14.15 \pm 0.13^{a}$ & $14.55 \pm 0.34^{a}$ & $0.32 \pm 0.02^{a}$ & $0.55 \pm 0.01^{a}$ \\
\hline CaChe & $3.69 \pm 0.02^{a}$ & $3.85 \pm 0.07^{a}$ & $14.20 \pm 0.27^{a}$ & $14.35 \pm 0.17^{a}$ & $0.43 \pm 0.02^{b}$ & $0.54 \pm 0.04^{a}$ \\
\hline$P$ value & 0.14 & 0.41 & 0.68 & 0.54 & 0.02 & 0.29 \\
\hline
\end{tabular}

* Mean values within the same column for each trait with the same lowercase letter are not significantly different according to Duncan's new multiple range test at $p \leq 0.05$.

except $\mathrm{CaChe}$ that gave higher TA in the first trial. The $p H$ of fruit flesh was around 3.77-3.86 in the first trial and 3.78-3.93 in the second trial. The values of TSS are not significantly different among all treatments and ranged from 13.90 to $14.70 \mathrm{wt} \%$, while TA ranged from 0.34 to $0.43 \mathrm{wt} \%$ in the first trial but increased and ranged from 0.48 to $0.55 \mathrm{wt}$ $\%$ in the second trial.

\subsection{Effects Calcium Spray on Sucrose, Fructose, and Glucose of} Pineapple Fruit. Calcium sprays did not affect the sucrose content in both trials (Table 5). The content of sucrose was around 9.52-9.96 wt\% in the first trial and a little lower in the second trial, which ranged from 8.77 to $9.76 \mathrm{wt} \%$. In the first, but not in the second trial, the fruit glucose content was significantly increased by calcium treatments. Application of $\mathrm{CaCl}_{2}$ gave the significantly lower content of glucose $(1.77 \mathrm{wt} \%)$ compared to control (2.15 wt\%) and $\mathrm{CaN}(2.06 \mathrm{wt} \%)$, and in the second trial, the glucose reduced compared to the first trial with the value ranging from 1.03 to $1.10 \%$ wt. In case of fructose, the content was also reduced in the second trial, with the value ranging from 0.30 to $1.06 \mathrm{wt} \%$, while in the first trial, it ranged from 1.08 to $1.35 \mathrm{wt} \%$. In the first trial, control and CaChe treatments have significantly higher values of fructose $(1.3$ and 1.29 wt\%, resp.) compared to $\mathrm{CaCl} 2$ (1.02 wt\%) and $\mathrm{CaB}(1.12 \mathrm{wt} \%)$.

3.3. Effect of Calcium on $\beta$-Carotene and Vitamin $C$ in Pineapple Fruit Flesh. The results showed that the contents of $\beta$-carotene and vitamin $C$ were not consistent in the first and second trials (Table 6). In the first trial, the application of calcium did not have any significant effect on $\beta$-carotene, while the content of vitamin $\mathrm{C}$ was almost the same in all treatments and not different from control. In the second trial, the calcium application had no significant effect on the content of vitamin $C$, and application of calcium tended to decrease the content of $\beta$-carotene in the fruit fresh. The value of $\beta$-carotene ranged from 2.58 to $3.09 \mathrm{wt} \%$ in the first trial and relatively did not change in the second trial, in which control gave the highest value (3.16 wt\%) and CaN had the lowest value (2.89 wt\%), while $\mathrm{CaB}, \mathrm{CaCl}$, and $\mathrm{CaChe}$ were not significantly different. For vitamin $C$, the value ranged from 294 to $353 \mathrm{wt} \%$ in the first trial and increased in the second trial and ranged from 386 to $449 \mathrm{wt} \%$.
3.4. Effect of Calcium Sprays on Fruit $\mathrm{Ca}$ and $\mathrm{Mg}$ Concentration. The calcium sprays did not give any difference in the content of $\mathrm{Ca}$ and $\mathrm{Mg}$ in the first trial (Table 7). In the second trial, the application of $\mathrm{Ca}$ in the form of $\mathrm{CaB}$ and $\mathrm{CaCl}$ increased $\mathrm{Ca}$ content compared to control, however no different result with $\mathrm{CaN}$ and $\mathrm{CaChe}$. The value of $\mathrm{Ca}$ in the first trial ranged from 95.53 to $109.41 \mathrm{mg} \mathrm{kg}^{-1}$ and increased in the second trial, which ranged from 97.981 to $28.50 \mathrm{mg} \mathrm{kg}^{-1}$. Application of $\mathrm{Ca}$ in the form of $\mathrm{CaN}, \mathrm{CaB}$, and $\mathrm{CaCl}$ gave a significant effect on the content of $\mathrm{Mg}$ in the second trial, resulting in higher content of $\mathrm{Mg}$ compared to control. The content of $\mathrm{Mg}$ ranged from 97.61 to $103.65 \mathrm{mg} \mathrm{kg}^{-1}$ in the first trial and from 81.201 to $11.00 \mathrm{mg} \mathrm{kg}^{-1}$ in the second trial.

3.5. Effect of Calcium on Electrolyte Leakage and Firmness of Pineapple Fruit. The application of calcium sprays did not give any difference in the firmness of the flesh fruit in both the first and second trials (Table 8). The firmness of pineapple fruit in the experiment ranged from 584.00 to $704.63 \mathrm{gf}$ in the first trial and from 578.75 to $691.00 \mathrm{gf}$ in the second trial. Among the forms of $\mathrm{Ca}$ treatment, only $\mathrm{CaCl}$ reduced EL in the first trial, while in the second trial, all the $\mathrm{Ca}$ treatments significantly reduced the EL compared to control. The lowest EL was found in $\mathrm{CaCl}$ treatment (47.77 wt\%) in the first trial, and the highest value was in control in the second trial $(72.58 \mathrm{wt} \%)$.

\section{Discussion}

As shown in Table 4, the application of calcium had no significant effect on $\mathrm{pH}, \mathrm{TSS}$, and TA in fruit flesh. These three parameters are mostly depended on the fruit maturity. The usual values of the $\mathrm{pH}$ in low acid hybrids fall in the range of 3.3 to 4.0 , decreasing as the fruit gets closer to harvest [22-25]. Therefore, the "MD-2" type was expected to have a high value compared to other cultivars $[24,26]$. The TSS and TA were also increased with the ripening stage [25].

The application of $\mathrm{Ca}$ did not have a significant effect on the content of sucrose (Table 5). This result is in accordance with the previous results; that is, a high calcium content may slow down fruit ripening and softening [27]. Fructose is the sweetest-tasting sugar, and the taste of the pineapple fruit is largely affected by the concentration of soluble sugars, organic acid, and fructose [28]. Consequently, the higher contents of fructose and glucose in the first trial revealed that 
TABLE 5: Effect of calcium sprays on sucrose, fructose, and glucose in fruit flesh.

\begin{tabular}{|c|c|c|c|c|c|c|}
\hline \multirow{2}{*}{ Treatment } & \multicolumn{2}{|c|}{ Sucrose (wt\%) } & \multicolumn{2}{|c|}{ Glucose (wt\%) } & \multicolumn{2}{|c|}{ Fructose $(w t \%)$} \\
\hline & $1 \mathrm{st}$ & $2 \mathrm{nd}$ & $1 \mathrm{st}$ & $2 \mathrm{nd}$ & $1 \mathrm{st}$ & 2nd \\
\hline Control & $9.96 \pm 0.26^{a}$ & $9.76 \pm 0.14^{a}$ & $2.15 \pm 0.06^{a}$ & $1.10 \pm 0.18^{a}$ & $1.35 \pm 0.03^{a}$ & $0.83 \pm 0.12^{a}$ \\
\hline $\mathrm{CaN}$ & $9.52 \pm 0.21^{a}$ & $9.55 \pm 0.40^{a}$ & $2.06 \pm 0.05^{a b}$ & $1.11 \pm 0.20^{a b}$ & $1.21 \pm 0.02^{a b}$ & $0.69 \pm 0.17^{a}$ \\
\hline $\mathrm{CaB}$ & $9.92 \pm 0.22^{a}$ & $9.70 \pm 0.16^{a}$ & $1.82 \pm 0.11^{b c}$ & $1.06 \pm 0.09^{c}$ & $1.12 \pm 0.01^{c}$ & $1.09 \pm 0.26^{a}$ \\
\hline $\mathrm{CaCl}$ & $9.87 \pm 0.31^{a}$ & $9.75 \pm 0.17^{a}$ & $1.77 \pm 0.08^{c}$ & $1.03 \pm 0.12^{c}$ & $1.08 \pm 0.02^{c}$ & $1.01 \pm 0.10^{a}$ \\
\hline CaChe & $9.92 \pm 0.16^{a}$ & $8.77 \pm 0.24^{b}$ & $2.04 \pm 0.06^{a b}$ & $1.40 \pm 0.11^{a b}$ & $1.29 \pm 0.03^{a b}$ & $1.06 \pm 0.09^{a}$ \\
\hline$P$ value & 0.69 & 0.05 & 0.02 & 0.26 & 0.00 & 0.42 \\
\hline
\end{tabular}

* Mean values within the same column for each trait with the same lowercase letter are not significantly different according to Duncan's new multiple range test at $p \leq 0.05$.

TABLE 6: Effect of calcium on $\beta$-carotene and vitamin $\mathrm{C}$ of pineapple fruit.

\begin{tabular}{lccrr}
\hline \multirow{2}{*}{ Treatment } & \multicolumn{2}{c}{$\beta$-Carotene (wt\%) } & \multicolumn{2}{c}{${\text { Vitamin C }\left(\mathrm{mg} \mathrm{kg}^{-1}\right)}^{2}$} \\
\hline Control & $2.73 \pm 0.03^{a}$ & $3.16 \pm 0.04^{a}$ & $333.27 \pm 11.66^{a b}$ & $437.34 \pm 2.10^{a}$ \\
$\mathrm{CaN}$ & $2.68 \pm 0.19^{a}$ & $2.89 \pm 0.03^{c}$ & $318.45 \pm 10.75^{a b c}$ & $386.72 \pm 11.43^{a}$ \\
$\mathrm{CaB}$ & $3.09 \pm 0.38^{a}$ & $3.07 \pm 0.06^{a b}$ & $302.56 \pm 16.30^{b c}$ & $428.27 \pm 22.40^{a}$ \\
$\mathrm{CaCl}$ & $2.81 \pm 0.19^{a}$ & $2.98 \pm 0.03^{b c}$ & $294.57 \pm 15.61^{c}$ & $449.72 \pm 38.25^{a}$ \\
$\mathrm{CaChe}$ & $2.58 \pm 0.04^{a}$ & $2.95 \pm 0.03^{b c}$ & $353.12 \pm 10.35^{a}$ & $406.11 \pm 5.81^{a}$ \\
$P$ value & 0.56 & 0.01 & 0.02 & 0.23 \\
\hline
\end{tabular}

* Mean values within the same column for each trait with the same lowercase letter are not significantly different according to Duncan's new multiple range test at $p \leq 0.05$.

TABLE 7: Effect of calcium sprays on calcium and magnesium of fruit flesh.

\begin{tabular}{lccrr}
\hline \multirow{2}{*}{ Treatment } & \multicolumn{2}{c}{ Calcium $\left(\mathrm{mg} \mathrm{kg}^{-1}\right)$} & \multicolumn{2}{c}{${\mathrm{Magnesium}\left(\mathrm{mg} \mathrm{kg}^{-1}\right)}^{2}$} \\
\hline Control & $1 \mathrm{st}$ & $9 \mathrm{nd}$ & $99.58 \pm 2.94^{a}$ & $81.20 \pm 3.99^{a}$ \\
$\mathrm{CaN}$ & $95.53 \pm 5.95^{a}$ & $109.55 \pm 14.92^{a b}$ & $97.61 \pm 4.66^{a}$ & $106.50 \pm 5.06^{c}$ \\
$\mathrm{CaB}$ & $94.28 \pm 11.62^{a}$ & $123.63 \pm 1.93^{b}$ & $102.74 \pm 0.93^{a}$ & $11.00 \pm 6.87^{c}$ \\
$\mathrm{CaCl}$ & $104.25 \pm 6.79^{a}$ & $128.50 \pm 3.97^{b}$ & $100.95 \pm 2.27^{a}$ & $95.80 \pm 2.47^{b c}$ \\
$\mathrm{CaChe}$ & $103.40 \pm 7.08^{a}$ & $117.78 \pm 3.08^{a b}$ & $103.65 \pm 2.60^{a}$ & $84.53 \pm 5.53^{a b}$ \\
$P$ value & $109.41 \pm 4.66^{a}$ & 0.09 & 0.59 & 0.01 \\
\hline
\end{tabular}

* Mean values within the same column for each trait with the same lowercase letter are not significantly different according to Duncan's new multiple range test at $p \leq 0.05$.

TABLE 8: Effect of calcium on electrolyte leakage and firmness of pineapple fruit.

\begin{tabular}{lcccc}
\hline \multirow{2}{*}{ Treatment $^{*}$} & \multicolumn{2}{c}{ Electrolyte leakage (wt\%) } & \multicolumn{2}{c}{ Firmness (gf) } \\
\hline Control & 1st & 2nd & 1st & $686.38 \pm 43.18^{a}$ \\
$\mathrm{CaN}$ & $52.31 \pm 0.87^{b}$ & $72.58 \pm 8.59^{b}$ & $584.00 \pm 35.47^{a}$ & $614.75 \pm 70.21^{a}$ \\
$\mathrm{CaB}$ & $51.63 \pm 1.04^{a b}$ & $49.39 \pm 6.00^{a}$ & $636.18 \pm 120.46^{a}$ & $57.00 \pm 86.27^{a}$ \\
$\mathrm{CaCl}$ & $50.12 \pm 2.28^{a b}$ & $55.36 \pm 3.68^{a}$ & $668.63 \pm 43.02^{a}$ & $67.75 \pm 81.21^{a}$ \\
$\mathrm{CaChe}$ & $47.77 \pm 0.64^{a}$ & $45.69 \pm 1.72^{a}$ & $704.63 \pm 9.25^{a}$ & $607.63 \pm 65.39^{a}$ \\
$P$ value & $52.56 \pm 0.96^{b}$ & $49.02 \pm 3.17^{a}$ & 0.69 & $619.00 \pm 51.42^{a}$ \\
\hline
\end{tabular}

${ }^{*}$ Mean values within the same column for each trait with the same lowercase letter are not significantly different according to Duncan's new multiple range test at $p \leq 0.05 .{ }^{* *}$ Control: untreated, $\mathrm{CaN}$ : calcium nitrate, $\mathrm{CaB}$ : calcium boron, $\mathrm{CaCl}$ : calcium chloride, CaChe: chelated calcium, wt: wet, and gf: gram force.

the treatment implemented together with the environmental conditions could have affected the outcomes of this trial. Moreover, the control, which had no application of calcium, showed high fructose and glucose contents. Calcium $\left(\mathrm{Ca}^{2+}\right)$ can delay the ripening and senescence-related processes of the fruit by the regulation of some signaling responses and the inhibition of the ethylene biosynthesis and respiration [29]. Therefore, when there was no calcium application, there was also no regulation of any signaling that may have reduced the sugar accumulation enzyme activities. 
In the case of the $\beta$-carotene, the results proved that treatments $\mathrm{CaN}, \mathrm{CaCl}$, and $\mathrm{CaChe}$ had the potential to reduce $\beta$-carotene significantly but not for treatment $\mathrm{CaB}$, especially in the second trial (Table 6). Carotenoids are responsible for the yellow color in the pineapple flesh, and this yellow color is known to increase during the final week before harvest $[24,30]$. $\beta$-Carotene, zeaxanthin, and $\beta$-apo8 '-carotenal are the main carotenoids of the pineapple fruit, with $\beta$-carotene being most predominantly responsible for the change in color through ripening $[14,31,32]$. The results of the second trial clearly demonstrated that when there was no application of calcium, the $\beta$-carotene content in the fruit tended to be higher compared to any treatment using a calcium source. There may be an effect related to the influence of calcium ions $\left(\mathrm{Ca}^{2+}\right)$ retarding the fruit ripening and therefore delaying the $\beta$-carotene molecule production. Nevertheless, this theory will require further investigation. Moreover, calcium is a major controller of cytosolic $p H$ and its associated signaling that its changes also contribute to activation and deactivation of many biochemical enzymes [3]. In case of the second trial, the influence of the environmental conditions was another factor that generated the significant differences displayed. The climatic conditions, especially the rain, could have created this situation in combination with the treatments employed in this study.

The vitamin C (ascorbic acid) content in the pineapple fruit depends on the cultivars and can vary from 200 to $710 \mathrm{mg} \mathrm{kg}^{-1}$. Several studies have found a significantly positive correlation between the ascorbic acid concentration and antioxidant activity among several cultivars [24, 33]. Ascorbic acid does not contribute substantially to titratable acidity, being 25\% higher near the surface of the fruit than near the core, and its level increases with increasing solar radiation and an increasing air temperature [24, 32]. The higher results for ascorbic acid in the second trial compared to the first trial revealed that, in this trial, the environmental conditions, namely, the solar radiation, influenced its elevated values. On the contrary, the applications of $\mathrm{CaChe}$ in the first trial generated the highest values for ascorbic acid at harvest; the opposite results were obtained when $\mathrm{CaCl}_{2}$ was used. $\mathrm{CaCl}_{2}$ is an inorganic salt used as a calcium source in many postharvest applications for pineapple [33]. There may have been an effect of this inorganic salt interacting with the formation of ascorbic acid molecules that generated low values at the harvest of the fruit.

The application of calcium did not increase the content of calcium in fruit flesh in the first trial but had a significant effect in the second trial (Table 7). In the second trial, $\mathrm{CaCl}_{2}$ generated the best performance in elevating the calcium level, followed by $\mathrm{CaB}$. $\mathrm{CaCl}_{2}$ has been used in several experiments to improve the shelf life and quality of pineapple fruit $[33,34]$. Ion $\mathrm{Ca}^{2+}$ is tied to calcium-dependent proteins, known as calmodulins (CaMs), calcineurin B-like proteins (CBLs), and calcium-dependent protein kinases (CDPKs) [25]. These proteins produce a downstream response, creating a higher solubility of the calcium, increasing its content in the plants, delaying the fruit senescence, and improving its quality $[29,35]$. It is clearly seen that $\mathrm{CaCl}_{2}$ could be a more appropriate calcium source for influencing the activity of these proteins and, because of that, bring about a higher content of it in the fruit.

Magnesium plays an important role in photosynthesis, improves chlorophyll content, and increases crop biomass and yield [36]; hence, the supply of carbohydrates and sugar to the growing fruit enhances its taste, size, and coloration [37]. Like the calcium content, the magnesium content in the fruit revealed significant differences only in the results of the second trial. In the second trial, $\mathrm{CaB}$ generated the highest level of magnesium content in the fruit, followed by $\mathrm{Ca}\left(\mathrm{NO}_{3}\right)_{2}$ and $\mathrm{CaCl}_{2}$, while no use of any calcium source (control) generated the lowest magnesium content (Table 7). It has been reported that magnesium in pineapple influences plant photosynthesis, growth, and chlorophyll concentration as an essential part of its molecules [14]. Moreover, boron has been linked to an increase in the rigidity of the cell wall matrix, affecting its polysaccharide constitution $[14,38]$. The reason why the $\mathrm{CaB}$ generated an increase in the magnesium content to its highest level in the fruit could be related to the support that the ion boron $\left(\mathrm{B}^{3+}\right)$ provided to the cell wall rigidity during its division and growth in the fruit, especially in the early stage of development. This situation could encourage higher assimilation of magnesium into the fruit, interacting positively with the boron when this calcium source was implemented. Nevertheless, further research should be carried out on this topic, as there is still not enough information to confirm this interaction.

Regarding EL, the results showed significant differences in both trials (Table 8 ). There was no large difference among the average values of every treatment, comparing the outcomes of the two trials, which corroborated the assumption that no other factors related to the treatments employed here affected the performance of this variable. $\mathrm{CaCl}_{2}$ brought about the lowest percentage of EL in both trials, while the control brought about the highest values. EL can be detected immediately after the existence of any stress factor impacting the plant. Therefore, it is considered to be a symbol of the plant response and tolerance to the biotic and abiotic stresses around it $[39,40]$. Studies have reported that the EL in pineapple fruit increases in parallel to the sucrose accumulation around six weeks before harvest [24, 41]. The results clearly show that the $\mathrm{CaCl}_{2}$ in both trials generated a reduction in EL, especially during the period of high sugar accumulation. This calcium source could have caused the higher assimilation of calcium ions into the cell wall matrix, as observed in the calcium content outcomes described previously. The rigidity of the cell wall matrix by higher calcium absorption permitted the regulation of the membrane permeability during several physiological processes of the plant, reducing the membrane leakage, which is associated with plant and fruit senescence [29].

No significant variance in the firmness of the flesh was displayed in the outcomes of each trial (Table 8). The values exhibited here are considered adequate for low acid hybrids in pineapple. The fruit firmness always decreases parallel to its ripening $[21,42,43]$. In the present study, when the fruit ripened from Stage 1 (mature green, $137 \pm 3$ days after forcing) to Stage 5 (100\% yellow, $177 \pm 3$ days after forcing), the firmness decreased significantly, namely, by $36 \%$ [17]. 


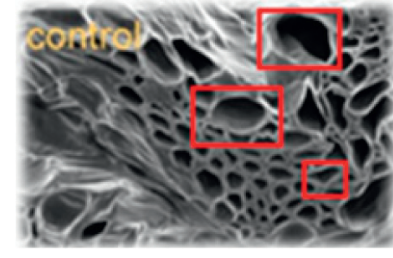

Control

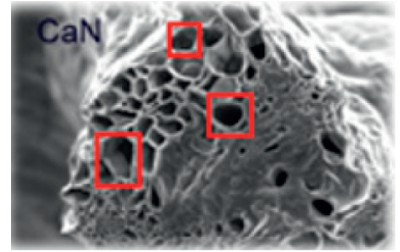

Calcium Nitrate

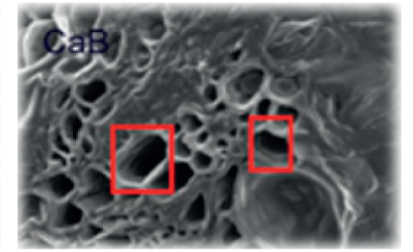

Calcium Boron

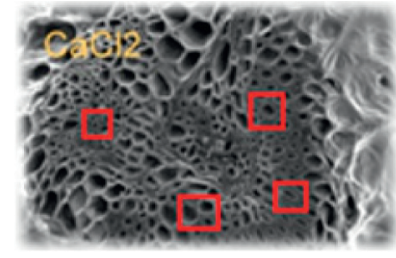

Calcium Chloride

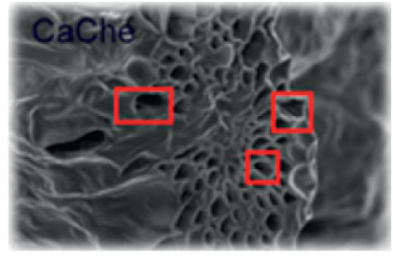

Chelated Calcium

FIgURE 1: Effect of calcium spray on the pineapple cell walls rigidity as shown in red boxes.

This situation is attributed to the physiological cell wall degradation due to several enzyme activities [21, 44]. Therefore, the results demonstrated that, regarding this variable, the treatments implemented here did not create any remarkable impact or noticeable variance, although firmness is still a parameter to be considered in terms of pineapple quality.

The SEM analysis results of the first trial revealed that $\mathrm{CaCl}_{2}$ generated a cell wall with more turgor and more rigidity in the pineapple fruit than the other treatments (Figure 1). These characteristics suggest that $\mathrm{CaCl}_{2}$ delivers more regulation of the membrane permeability and no separation of the vascular section of the cell body. The cell wall is composed of a primary layer and a secondary layer. The primary layer, which is evidenced in the SEM analysis, is comprised of cellulose, hemicelluloses, and pectin [45]. Furthermore, in pineapple fruit, cellulose accounts for $41.8 \%$, followed by hemicellulose at $33.6 \%$ and pectin at $21.2 \%[21,46]$. Based on these values, $\mathrm{CaCl}_{2}$ would also be more prone to reduce the activity of cell wall-degraded enzymes like polygalacturonase (PG) $[29,47]$. PG, or pectinase, is an enzyme that can depolarize pectin in the cell wall matrix, creating its breakdown and subsequent leakage $[29,47]$.

\section{Conclusion}

Calcium sprays have not influenced fruit $p H$, TSS, TA, firmness, sucrose, glucose, fructose, and vitamin C consistently. There was a different response of calcium spray in the first and second trials on the content of glucose, fructose, $\beta$-carotene, $\mathrm{Ca}$, and $\mathrm{Mg}$, probably due to climate conditions. The content of glucose and fructose was not significantly different among the treatment in the second trial, while that of $\beta$-carotene, $\mathrm{Ca}$, and $\mathrm{Mg}$ was not different in the first trial. All treatments with calcium sprays, especially calcium chloride or $\mathrm{CaCl}_{2}$ and calcium boron, reduced the fructose and glucose contents considerably in the first trial. Furthermore, the $\beta$-carotene content decreased significantly when the pineapple was treated with
$\mathrm{CaCl}_{2}$, chelated calcium, or $\mathrm{Ca}\left(\mathrm{NO}_{3}\right)_{2}$ in the second trial. The calcium content in the fruit flesh increased significantly compared to that in the control when the pineapple was treated with $\mathrm{CaCl}_{2}$ or calcium boron in the second trial, although no significant differences were seen in the first trial. Calcium sprays could decrease EL in both the first and second trials, and $\mathrm{CaCl}_{2}$ brought about the lowest percentage of EL in both trials. The scanning electron microscope analysis revealed that $\mathrm{CaCl}_{2}$ sprays at $75 \mathrm{~kg}$ $\mathrm{ha}^{-1}$ generated greater turgor and more rigidity in the pineapple cell wall. The result showed that the application of $\mathrm{CaCl}_{2}$ and calcibor sprays could decrease EL incidence in pineapple with any potential to reduce glucose, fructose, and $\beta$-carotene without influencing other fruit quality standards significantly.

\section{Data Availability}

The data used to support the findings of this study are available from the corresponding author upon request.

\section{Conflicts of Interest}

The authors declare that they have no conflicts of interest.

\section{Acknowledgments}

This research was funded by PT. Great Giant Pineapple (GGP), Lampung, Indonesia (L/RD-PA-NPT/03.21), and a part of the research was supported by RONPAKU-Program of UGSAS-Gifu University, Japan. The authors would like to express their gratitude to the United Graduate School of Agricultural Science (UGSAS), Gifu University, Japan, for the support and funding provided for this research through the Ronpaku Program. Sincere thanks are also extended to the Management of PT. Great Giant Pineapple, for permitting, funding, and supporting this study. Thanks are also extended to the R\&D PT. GGP colleagues, Mr. Ziaurrahman and Mr. Diego, for their support during the analysis in the laboratory. 


\section{References}

[1] R. E. Paull and N. J. Chen, "Tropical fruits: pineapples," in Controlled and Modified Atmospheres for Fresh and Fresh-Cut Produce, M. I. Gil and R. Beaudry, Eds., Academic Press, Cambridge, MA, USA, pp. 381-388, 2020.

[2] R. B. H. Wills, W. B. McGlasson, D. Graham, T. H. Lee, and E. G. Hall, Post Harvest: An Introduction to the Physiology and Handling of Fruit and Vegetables, Blackwell Scientific, Boston, MA, USA, 1981.

[3] M. C. Saure, "Calcium translocation to fleshy fruit: its mechanism and endogenous control," Scientia Horticulturae, vol. 105, no. 1, pp. 65-89, 2005.

[4] Y. A. Y. Leshem, "The role of calcium in the membrane," in Plant Membrane, a Biophysical Approach to Structure, and Senescence, pp. 157-173, Kluwer Academic Publishers, Norwell, MA, USA, 1992.

[5] L. Taiz, E. Zeiger, and I. M. Moller, Plant Physiology and Development, Sinaur Associates, Sunderland, MA, USA, 6th edition, 2015.

[6] I. G. Hewajulige, S. Wilson Wijeratnam, and R. L. Wijesundera, "Pre-harvest application of calcium to control black heart disorder in Mauritius pineapples during low-temperature storage," Journal of the Science of Food and Agriculture, vol. 86, no. 3, pp. 420-424, 2006.

[7] R. R. Dayondon and V. C. Valleser, "Effects of urea and calcium-boron applied at flower-bud stage on 'MD-2' pineapple fruit," International Journal of Scientific and Research Publications, vol. 8, no. 6, pp. 322-328, 2018.

[8] S. M. Bakeer, "Effect of ammonium nitrate fertilizer and calcium chloride foliar spray on fruit cracking and sunburn of Manfalouty pomegranate trees," Scientia Horticulturae, vol. 209, pp. 300-308, 2016.

[9] P. Wójcik, J. Filipczak, and M. Wójcik, "Effects of prebloom sprays of tryptophan and zinc on calcium nutrition, yielding and fruit quality of 'Elstar' apple trees," Scientia Horticulturae, vol. 246, pp. 212-216, 2019.

[10] T. E. Lobos, J. B. Retamales, and E. J. Hanson, "Early preharvest calcium sprays improve postharvest fruit quality in 'Liberty' highbush blueberries," Scientia Horticulturae, vol. 277, 2021.

[11] B. Ozturk, E. Aglar, O. Karakaya, O. Saracoglu, and S. Gun, "Effects of preharvest $\mathrm{GA} 3, \mathrm{CaCl} 2$ and modified atmosphere packaging treatments on specific phenolic compounds of sweet cherry," Turkish Journal of Food and Agriculture Sciences, vol. 1, no. 2, pp. 44-56, 2019.

[12] L. A. Brandt, "Formulation challenge: calcium the essential mineral," 2003, https://www.preparefoods.com/archies/2003.

[13] A. B. Martín-Diana, D. Rico, J. M. Frías, J. M. Barat, G. T. M. Henehan, and C. Barry-Ryan, "Calcium for extending the shelf life of fresh whole and minimally processed fruits and vegetables: a review," Trends in Food Science \& Technology, vol. 18, no. 4, pp. 210-218, 2007.

[14] J. Vásquez-Jiménez and D. P. Bartholomew, "Postharvest physiology, handling and storage of pineapple," in The Pineapple: Botany, Production and Uses, G. M. Sanewski, D. P. Bartholomew, and R. E. Paull, Eds., pp. 175-202, CABI, London, UK, 2nd edition, 2018.

[15] C. Chen and R. E. Paull, "Changes in sugar contents and activities of sugar metabolizing enzymes in pineapple fruit flesh during development," Acta Horticulturae, vol. 529, no. 529, pp. 191-198, 2000.

[16] R. Shamsudin, W. R. W. Daud, M. S. Takriff, and O. Hassan, "Physicochemical properties of the Josapine variety of pineapple fruit," International Journal of Food Engineering, vol. 3, no. 5, pp. 1-12, 2007.

[17] P. Ding and S. Syazwani, "Physicochemical quality, antioxidant compounds and activity of MD-2 pineapple fruit at five ripening stages," International Food Research Journal, vol. 23, no. 2, pp. 549-555, 2016.

[18] J. Benton-Jones Jr, Laboratory Guide for Conducting Soil Tests and Plant Analysis 1st Ed, CRC Press, Boca Raton, FL, USA, 2001.

[19] A. M. Siti Roha, S. Zainal, A. Noriham, and K. Z. Nadzirah, "Determination of sugar content in pineapple waste variety N36," International Food Research Journal, vol. 20, no. 4, pp. 19411-19943, 2013.

[20] S. O. Owolade, A. O. Akinrinola, F. O. Popoola, O. R. Aderibigbe, O. T. Ademoyegun, and I. A. Olabode, "Study on physico-chemical properties, antioxidant activity and shelf stability of carrot (Daucus carota) and pineapple (Ananas comosus) juice blend," International Food Research Journal, vol. 24, no. 2, p. 534, 2017.

[21] H. Hu, X. Li, C. Dong, and W. Chen, "Effects of wax treatment on the physiology and cellular structure of harvested pineapple during cold storage," Journal of Agricultural and Food Chemistry, vol. 60, no. 26, pp. 6613-6619, 2012.

[22] S. Syazwani, I. Nurliya, and P. Ding, "Storage quality of "MD2" pineapple (Ananas comosus L.) fruits," in Proceedings of the VII International Postharvest Symposium, pp. 897-901, Kuala Lumpur, Malaysia, June 2012.

[23] K. Z. Nadzirah, S. Zainal, A. Noriham, I. Normah, M. Siti Roha, and H. Nadya, "Physico-chemical properties of pineapple variety $\mathrm{N} 36$ harvested and stored at different maturity stages," International Food Research Journal, vol. 20, no. 1, pp. 225-231, 2013.

[24] R. E. Paull and C. C. Chen ChingCheng, "Postharvest physiology, handling and storage of pineapple," in The Pineapple: Botany, Production and Uses, G. M. Sanewski, D. P. Bartholomew, and R. E. Paull, Eds., pp. 295-323, CABI, London, UK, 2nd edition, 2018.

[25] B. A. M. S. Kumara and K. D. T. Hettige, "Ripening stage affects the quality of fresh and dehydrated pineapples (Ananas comosus (L.) Merr.) cv. Mauritius in Sri Lanka," Sustainable Food Production, vol. 8, pp. 29-37, 2020.

[26] N. J. Chen and R. E. Paull, "Production and postharvest handling of low acid hybrid pineapple," Acta Horticulturae, vol. 1166, pp. 253-260, 2017.

[27] I. B. Ferguson, "Calcium in plant senescence and fruit ripening," Plant, Cell and Environment, vol. 7, no. 6, pp. 477-489, 1984.

[28] D. Elsa, G. Yves, B. Valentina, S. Veronique, G. Michel, and Q. T. Benedicte, "Profiling sugar metabolism during fruit development in a peach progeny with different fructose-toglucose ratios," Plant Biology, vol. 14, no. 336, pp. 2-13, 2014.

[29] S. T. De Freitas and R. C. M. Nassur, "Calcium treatments," in Novel Postharvest Treatments of Fresh, S. Pareek, Ed., CRC Press, Boca Raton, FL, USA, pp. 52-68, 2017.

[30] G. M. Sun, "Pineapple production and research in China," in Proceedings of the VII International Pineapple Symposium 902, pp. 79-85, Johor, Malaysia, July 2010.

[31] C. B. Steingass, K. Vollmer, P. E. Lux, C. Dell, R. Carle, and R. M. Schweiggert, "HPLC-DAD-APCI-MSn analysis of the genuine carotenoid pattern of pineapple (Ananas comosus [L.] Merr.) infructescence," Food Research International, vol. 127, Article ID 108709, 2020.

[32] E. A. Ferreira, H. E. Siqueira, E. V. V. Boas, V. S. Hermes, and A. O. Rios, "Bioactive compounds and antioxidant activity of 
pineapple fruit of different cultivars," Revista Brasileira de Fruticultura, vol. 38, no. 3, pp. 1-7, 2016.

[33] P. Youryon, S. Supapvanich, P. Kongtrakool, and C. WongsAree, "Calcium chloride and calcium gluconate peduncle infiltrations alleviate the internal browning of Queen pineapple in refrigerated storage," Horticulture, Environment, and Biotechnology, vol. 59, no. 2, pp. 205-213, 2018.

[34] I. Pusittigul, J. Siriphanich, and C. Juntee, "Role of calcium on internal browning of pineapples," Acta Horticulturae, vol. 1024, no. 1024, pp. 329-338, 2014.

[35] M. S. Aghdam, M. B. Hassanpouraghdam, G. Paliyath, and B. Farmani, "The language of calcium in postharvest life of fruits, vegetables and flowers," Scientia Horticulturae, vol. 144, pp. 102-115, 2012.

[36] S. Yeboah, J. Asibuo, P. Oteng-Darko et al., "Impact of foliar application of zinc and magnesium aminochelate on bean physiology and productivity in Ghana," International Journal of Agronomy, vol. 2021, Article ID 9766709, 9 pages, 2021.

[37] Anonymous, "Pineapple. $\mathrm{K}+\mathrm{S}$ minerals and agricultural $\mathrm{GmbH}$," www.ks-minerals-and- agriculture.com/uken/fertilizer/advisory_service/crops/pineapple.html, 2020.

[38] E. R. Lampugnani, G. A. Khan, M. Somssich, and S. Persson, "Building a plant cell wall at a glance," Journal of Cell Science, vol. 131, no. 2, 2018.

[39] M. Bajji, J.-M. Kinet, and S. Lutts, "Osmotic and ionic effects of $\mathrm{NaCl}$ on germination, early seedling growth, and ion content of Atriplex halimus (Chenopodiaceae)," Canadian Journal of Botany, vol. 80, no. 3, pp. 297-304, 2002.

[40] V. Demidchik, D. Straltsova, S. S. Medvedev, G. A. Pozhvanov, A. Sokolik, and V. Yurin, "Stress-induced electrolyte leakage: the role of $\mathrm{K}+$-permeable channels and involvement in programmed cell death and metabolic adjustment," Journal of Experimental Botany, vol. 65, no. 5, pp. 1259-1270, 2014.

[41] R. E. Paull and C. C. Chen ChingCheng, "Postharvest physiology, handling and storage of pineapple," in The Pineapple: Botany, Production and Uses, D. P. Bartholomew, R. E. Paull, and K. G. Rohrbach, Eds., CABI Publishing, London, UK, pp. 253-279, 2003.

[42] G. Tucker, X. Yin, A. Zhang et al., "Ethylene† and fruit softening," Food Quality and Safety, vol. 1, no. 4, pp. 253-267, 2017.

[43] J. Gao, Y. Zhang, Z. Li, and M. Liu, "Role of ethylene response factors (ERFs) in fruit ripening," Food Quality and Safety, vol. 4, no. 1, pp. 15-20, 2020.

[44] D. A. Brummell and M. H. Harpster, "Cell wall metabolism in fruit softening and quality and its manipulation in transgenic plants," Plant Cell Walls, vol. 47, pp. 311-340, 2001.

[45] M. C. Jarvis, "Plant cell walls: supramolecular assemblies," Food Hydrocolloids, vol. 25, no. 2, pp. 257-262, 2011.

[46] C. Vidal-Valverde, J. Herranz, I. Blanco, and E. Rojas-Hidalgo, "Dietary fiber in Spanish fruits," Journal of Food Science, vol. 47, no. 6, pp. 1840-1845, 1982.

[47] B. Hocking, S. D. Tyerman, R. A. Burton, and M. Gilliham, "Fruit calcium: transport and physiology," Frontiers in Plant Science, vol. 7, p. 569, 2016. 